\title{
The Admission Policy Test and Effectiveness of Islamic Education in a Secular State
}

\author{
Nhelbourne K. Mohammad \\ University of Muhammadiyah Malang \\ nhelkm1980@gmail.com \\ Muhammad Siri Dangnga \\ Muhammadiyah University of Parepare \\ muhammad.siri@gmail.com
}

\author{
St. Nurhayati \\ Institut Agama Islam Negeri Parepare \\ nurhayatimahsyar@gmail.com \\ Mahsyar \\ Institut Agama Islam Negeri Parepare \\ nurhayatimahsyar@gmail.com
}

\begin{abstract}
Verily, the purpose of Islamic education is to produce a perfect human being to develop their potentials, mental, emotional physical, spiritual, and harmonizing connection to the Almighty God. For deeply understanding, the significance of Islamic education is needed in order to clarify understanding of human being concept or mind in accordance of Islamic point of views and to create men to be a better man with religious oriented, and to worship God alone, and following the footstep of the Prophet Muhammad (PBUH) in a sense of manner. The Islamic education in a secular state is facing difficulties particularly in the Southern part of the Philippines. Apparently, the Moslem Filipino scholars couldn't fully impose and implement their own standard Islamic education system in the country. Therefore, one of the main objectives of Moro Moslem revolution in Mindanao is to have their own standard education system specifically for Islamic education that truly reflects their own cultures and traditional practices. This study is aimed to describe the Islamic education in a secular state in terms of admission policy and the quality effectiveness of the Islamic educational curriculum. The study method was done by a qualitative approach.
\end{abstract}

Keywords: Islamic Education, Admission Test, Effectiveness

\section{INTRODUCTION}

The Moslem community in the Philippines strongly needs an Islamic education system which is truly reflecting their own cultures and traditional practices. Being a Filipino citizen, the Moslem community in this country is seeking their rights and wants to maintain their own schools that live up its standard. In the early 1970's, the Moro Moslem rebellion might have forced the attention of President Marcos on how the importance of Islamic education for Moro in Mindanao. During the Martial Law, Marcos noted this problem; therefore, he then created the Institute of Islamic Studies by the virtue of Presidential Decree (PD) No. 342 on November 22, 1973. A purpose of the creation of PD No. 342 was the abolishing the Executive Order (EO) No. 543 which issued by Marcos on July 9, 1979 to recreate Islamic studies as a separate institute of the university that aimed to produce intellectual university students opportunity to be participated in their life and development in the country both Christian and Moslem. Islamic institute here is the Institute of Islamic Studies at the University of the Philippines Diliman and at King Faisal Institute of Islamic and Arabic Studies in Mindanao State University Main Campus which was built in 1974 recognizing and gratitude of Moro Moslem to the late King Faisal of the Royal Kingdome of Saudi Arabia who supports the establishment of this institution and granted scholarship for the Moro Moslem in Mindanao [1].

The Philippine government planned to create a standard university in Mindanao through a higher education program that aims to accelerate the western education curriculum and speed up to civilization, educating, and professionalizing the Moro Moslem in the country. Through this government standard educational system, the Moro increases their professionals and educators and teaching them literature, philosophy, technical writing, arts, and sciences. Also, liberating and learn to understand the origin of Filipino cultures and traditional practices in the country. The history tells us, the US Ambassador; William E. Stevenson earlier predicted that Mindanao State University which set up in the central plan of Moro homeland is very important binding the cultures of Moro Moslem and Christians in the Southern Philippines[2].

The creation of Mindanao State University (MSU) located in Marawi City and other provinces in Mindanao was the government answered for the Moro revolutionary movement especially the students who want to pursue their higher education and live peacefully to represent Moslem in the Southern Philippines both Christians and Moslems were living together in a harmony, tranquility and peacefully. MSU is one of the best state universities in the Philippines under the management of Commission on Higher Education (CHED). This University also offered Islamic studies with different major such as sharia law and Islamic banking \& finance. This kind of education system is growing fastest but actually very difficult to remove the origin of Moro cultures. Marawi 
City is the center of Islamic education in both western and Islamic education of the Filipino Moslem, besides the MSU, represent western education system, they have also madrasah, Mahad, and Jamiat Islam (Islamic University), the curricula and education policies they used were adopted from the Middle East and purely Arabic means of instruction[3].

The Republic Act (RA) No. 9054, a creation of Autonomous Region of Muslim in Mindanao (ARMM) was part of the Peace Process Agreement of the Philippine Government (GPH) between Moro National Liberation Front (MNLF). This Act No. 9054 like among others Act, remarkable features which guarantee for building up of a mechanism to mainstreaming Islamic education in the Southern Philippines. hence, the Department of Education (DepEd) or known before Department of Education Culture and Sports (DECS) was the main part by spreading the interregional cultures program that Islamic values and basic Arabic grammar to be included in the Department of Education Curriculum particularly in Moro Moslem areas like A.L.I.V.E. (Arabic Language and Islamic Education Program) Program [4]-[5]-[6].

\section{METHOD}

The research method was done by a qualitative approach. The researcher was come out to the necessary field of study to collect the data through oral interviews and actual observations. Data was collected from all students in the class. The researcher conducted this research using oral interviews with the students in the classes and carried out actual observations. This study was conducted one year ago at Cotabato State University in Cotabato City. In the year 2017, there are only 16 firstyear students were enrolled in Islamic education. 14 students were the presence in the classes during the observations and interviews out of 16 students in this class. The researcher asked 10 students and 5 teachers regarding the effectiveness of the Islamic educational curriculum in the secular state like the Philippines which is about $85 \%$ are the Roman Catholic and only $11 \%$ are Moslem, the rest are other non-Moslem religions or according to the census in 2016 .

\section{RESULT}

\section{Admission Test}

The result of the study is based on the statement problems stated in the introduction to the study. The standard Policy on Admission Test at Cotabato State University shall be prescribed by the faculty of the college or unit offering the courses, subject to the approval of Academic Council and the confirmation of the Board of Trustees. Foreign students shall be required to meet substantially the requirements prescribed for their admission to the college. They must submit a valid study permit from the Commission on Higher Education (CHED) or transfer credentials if they have previously enrolled in another school in the Philippines. The basic requirements eligibility for admission of a student to any tertiary level or undergraduate degree program shall be graduation from the secondary level recognized by the Department of Education. Also, must have a system of selective admissions into the programs for the teacher education. These criteria shall include passing a standardized admission test. The students who do not meet the minimum cut-off scores in the standardized admission test may be admitted under probation. However, they must meet certain minimum retention requirements to best by the school before the students can precede the major/professional education course (CMO No.30, 2008).

The state colleges and universities in the Philippines have a standard Policy and Requirements on Admission for freshmen and transfer students, this is so called, Admission Test or Entrance Examination. In the University of the Philippines (UP) it is commonly known as UPCAT (University of the Philippines College Admission Test), is part of the admission test requirements of the University of the Philippines, administered to the graduates of Philippine and foreign high schools. UPCAT was first administered in 1968. This policy is mandated by the Commission on Higher Education (CHED). The Admission Test has time limits about five-hour exam covers language proficiency, reading comprehension, mathematics, and science.

Usually, the admission test held on Saturday and Sunday in the morning and the afternoon. The test questions are written in English but sometimes in Filipino. This test is required for freshmen and transferee student only, which shall serve as one of the bases to determine the fitness of the students to the course he intends to enroll in. As a prerequisite, every applicant for admission shall be required to pass a thorough physical, medical and other examinations, as may be deemed wise, to be conducted by the medical and dental units of the College. Government employees seeking admission to the College shall be required to submit the following: a) permit to study signed by his agency head or his duly authorized representative; b) original copy of Transcript of Records (CMO No.30, 2008).

According to Dean Macrina, the previous IIS at UP Diliman had offered the undergraduate degree, Bachelor of Arts in Islamic Studies, but suddenly the University had closed the undergraduate degree program due to the decreasing of the number of enrollees. UP has a standard and strictly Admission Test Competency, so some of the students who have not passed the Admission Test is no longer having a change to enrolled in this University, in fact, the number of enrollees is very small because the University is put in National Capital Region which is Muslim is the minority. The chairman of Islamic Education program stated on the admission policy test in Cotabato State University (CSU) has a standard policy and prerequisite for Entrance Examination or Admission Test for the freshmen and transferee students. The freshmen and transferee students could not enroll in any courses unless they have undergone and should be passed the minimum score or the passing grades of not less than 
75 percent. In short, students shall not be denied for admission to higher education by just the reasons of nationality, belief or political affiliation, sex or status and age. The Admission Test or UPCAT is being implemented from all over the country. No students should be allowed to enroll at any state universities and colleges in the country unless they have undergone and pass the Admission Test as well as in the private universities and colleges. When the students have passed the Admission Test, the Islamic Education Program has their own local policy too.

\section{Curriculum Effectiveness}

An Islamic education at Cotabato State University has been challenged with poor educational facilities and buildings. Limited classrooms have been built just to accommodate very few students. The classrooms are not conducive to learning. The buildings are not supposed to be built for education. Besides, masjid institutions are poorly managed and administered. This is one of the factor cases encountered in implementing the Islamic education or institute of Islamic studies in the country, the government did not fully support this program. Some local big families and political leaders give attention to any Islamic institution are for certain cases particularly during the election only in order to get the sympathy of the Muslim voters.

The Quality of education offered in Islamic education program presently does not give much scope for the students to develop as modern human beings. The reason for the gradual decline of a program is due to the absence of qualified teachers who in some ways can contribute to the fast-growing improvement of the program. Higher graduates of Islamic teachers were mostly teachers in Islamic schools in local communities. It is of great importance to stress that science education coupled with modern technology will be used in Islamic education program properly; it would make the Islamic education meaningful. Islam is comprehensive religion. Moslems are allowed to have plenty of relevant information and knowledge about modern education so that they can adjust themselves to any challenges and confrontations.

Mostly the traditional or non-formal madrasah education program in the Philippines has no government accreditations. Islamic schools have been running under the supervision of the Muslim communities or local leaders. The absence of national accreditation in all Madrasah educations in the Philippines is the obstacle to a higher degree. Most of the subjects in Madrasahs are religious subjects without the further inclusion of the scientific subjects such as mathematics, economics, politics, sociology, English Language and computer. Since only religious subjects that governed the curriculum of Madrasah, the government cannot able to grant accreditation for those educational institutions that cannot reach the government standard requirements.

\section{CONCLUSION}

The study talks about the admission policy test and effectiveness of the teachers in Islamic education program. The students are enjoying in learning of Islamic education because the teachers in this department are very productive and most of them are foreign graduates. Students encountered some difficulties in admission policy test, but they are willing to study in this University due to the standard educational system and cheapest tuition fee. The Islamic education at Cotabato State University is very important which played the vital role in Cotabato City because of this University the only hopes of the young Bangsamoro (Filipino Moslem) center for western education. Education is important both secular and Islamic education educating the Moro people in the Southern Philippines.

In the real world having a minority Muslim population, the development and dynamics of Islamic education in the Philippines is beset by multifarious challenges. The most fundamental of which is the opposite views of the Islamic and the Western cultures on education as the former calls for the total development of a person both in his physical as well as spiritual life, while the latter concentrates only on the secular side. On this note, the Moro people are not an exception to this impediment. In fact, their greatest challenge with respect to their Islamic education is how could their Islamic system of life be finally accommodated and made part of the broader Filipino culture which is largely patterned from the West.

\section{REFERENCES}

[1] T. Ab. Halim, A. G. Kamarulzaman, and H. Azmil, "Islamic Education: Planning For The Future Of Muslim World," in International Conference on Islamic Education (ICIEd 2010), 2010.

[2] S. M. N. Al-Attas, "The Concept of Islamic Education," keynote address Deliv. First World Conf. Muslim Educ., 1980.

[3] A. H. Tamuri, M. F. Ismail, and K. A. Jasmi, "A New Approach in Islamic Education: Mosque Based Teaching and Learning," J. Islam. Arab. Educ., 2012.

[4] Y. Waghid, "Islamic education," in International Encyclopedia of Education, 2010.

[5] Farid Mat Zain, Wan Kamal Mujani, and Ibrahim Abu Bakar, "The Islamic Education and The ' $\mathrm{j}$ QAF' Program in Malaysia 1," Adv. Nat. Appl. Sci., 2012.

[6] D. Al Hamdani, "THe Character Education in Islamic Education Viewpoint," J. Pendidik. Islam, 2016.

[7] "Researcher went to interview with the chairman, faculty, and staff of Islamic education program on policy and curriculum implementation, including other Islamic activities concerns of Cotabato State University, dated on March 13, 2017.," 2017. 